\title{
A monospecific assemblage of terebratulide brachiopods in the Upper Cretaceous seep deposits of Omagari, Hokkaido, Japan
}

\author{
Andrzej Kaim, Maria Aleksandra Bitner, Robert G. Jenkins, and Yoshinori Hikida \\ Acta Palaeontologica Polonica 55 (1), 2010: 73-84 doi: http://dx.doi.org/10.4202/app.2009.0068
}

The Campanian (Upper Cretaceous) seep carbonate at Omagari (Hokkaido, Japan) yields a monospecific association of the terebratulide brachiopod Eucalathis methanophila Bitner sp. nov. The association is the only occurrence of brachiopods known from the post-Early Cretaceous history of chemosynthesis-based communities. Unlike many earlier rhynchonellide-dominated hydrocarbon seep associations-which disappeared in Aptian times-this association is composed of chlidonophorid terebratulides. It is hypothesised here that large rhynchonellide brachiopods have been outcompeted from chemosynthesis-based associations by large chemosymbiotic bivalves (especially lucinids) and that this seep association containing numerous terebratulide brachiopods originated as a result of immigration from the background fauna settling in a seep that lacked numerous large bivalves but offered some hard substrates for brachiopod attachment. Some living chlidonophorids are known to settle around seep/vent localities or more generally in deep-water hard-substrate settings. We review occurrences of brachiopods in chemosynthesis-based associations and show that brachiopods immigrated repeatedly to seep/vent environments. Eucalathis methanophila Bitner sp. nov. represents the oldest and single Mesozoic record of the genus. The new species is similar in ornamentation to three living species, Indo-Pacific E. murrayi, eastern Atlantic E. tuberata, and Caribbean E. cubensis but differs in having a higher beak and wider loop. Additionally the studied species is nearly twice as large as E. tuberata.

Key words: Brachiopoda, Chlidonophoridae, Eucalathis, hydrocarbon seep, chemosynthesis-based community, Campanian, Cretaceous, Mesozoic, Japan.

Andrzej Kaim [kaim@twarda.pan.pl] and Maria A. Bitner [bitner@twarda.pan.pl ], Instytut Paleobiologii PAN, ul. Twarda 51/55, 00-818 Warszawa, Poland; Robert G. Jenkins [robertgj@ori.u-tokyo.ac.jp], HADEEP, Ocean Research Institute, University of Tokyo, 1-15-1 Minamidai, Nakano-ku, Tokyo 164-8639, Japan; Yoshinori Hikida [nmhikida@coral.ocn.ne.jp], Nakagawa Museum of Natural History, Hokkaido 068-0835, Japan. 
This is an open-access article distributed under the terms of the Creative Commons Attribution License (for details please see creativecommons.org), which permits unrestricted use, distribution, and reproduction in any medium, provided the original author and source are credited.

\footnotetext{
FoF Full text $(761.5 \mathrm{kB})$ ।

FoFif- Supplementary file $(1,005.1 \mathrm{kB})$
} 